\title{
An Update on Familial Hyperaldosteronism
}

\author{
Authors \\ H. E. Korah, U. I. Scholl \\ Affiliation \\ Department of Nephrology, Medical School, Heinrich Heine University, University Hospital Düsseldorf, Düsseldorf, \\ Germany
}

Key words
GRA
PASNA
primary aldosteronism
KCNJ5
CACNA1D
CACNA1H

received 06.08 .2015

accepted 10.09.2015

Bibliography

DOI http://dx.doi.org/

10.1055/s-0035-1564166

Published online:

October 7, 2015

Horm Metab Res 2015;

47: 941-946

(c) Georg Thieme Verlag KG

Stuttgart · New York

ISSN 0018-5043

Correspondence

Jun.-Prof. Dr. U. I. Scholl

Department of Nephrology

Medical School

Heinrich Heine University

Moorenstraße 5

40225 Düsseldorf

Germany

Tel.: +49/211/81 10845

Fax: $+49 / 211 / 8101504086$

ute.scholl@med.uni-

duesseldorf.de

\section{Abstract \\ $\nabla$}

Familial forms of primary aldosteronism have been suggested to account for up to $6 \%$ of cases in referral centers. For many years, the genetics of familial hyperaldosteronism remained unknown, with the notable exception of glucocorticoid-remediable aldosteronism, due to unequal crossing over and formation of a chimeric 11 $\beta$-hydroxylase/ aldosterone synthase gene. Over the past 5 years, mutations in 3 additional genes have been shown to cause familial forms of primary aldosteronism. Gain-of-function heterozygous germline mutations in KCNJ5, which encodes an inward rectifier potassium channel, cause autosomal dominant syndromes of PA and hypertension with or without adrenal hyperplasia. Germline mutations in

\section{Abbreviations \\ $\nabla$ \\ ACTH Adrenocorticotropic hormone \\ APA Aldosterone-producing adenoma \\ CACNA1D Calcium channel, voltage-dependent, L type, alpha 1D subunit CACNA1H Cal- cium channel, voltage-dependent, $\mathrm{T}$ type, alpha $1 \mathrm{H}$ subunit \\ CYP11B1 Cytochrome P450, family 11, subfamily B, polypeptide 1 \\ CYP11B2 Cytochrome P450, family 11, subfamily B, polypeptide 2 \\ $\mathrm{FH} \quad$ Familial hyperaldosteronism \\ GRA Glucocorticoid-remediable aldoster- onism \\ KCNJ5 Potassium channel, inwardly rectify- ing subfamily J, member 5 \\ PA Primary aldosteronism \\ PASNA Primary aldosteronism, seizures, and neurologic abnormalities}

CACNA1D, which codes for an L-type calcium channel, have so far only been found in 2 cases with a syndrome of primary aldosteronism, seizures, and neurologic abnormalities. Both KCNJ5 and CACNA1D mutations in familial hyperaldosteronism were only discovered following identification of similar or identical somatic mutations in aldosterone-producing adenomas. In contrast, a recent exome sequencing study identified germline mutations in CACNA1H (a T-type calcium channel), previously undescribed in adenomas, in 5 unrelated families with early-onset primary aldosteronism and hypertension, without any additional shared symptoms. Future exome or genome sequencing studies are expected to shed light on the genetic basis of many cases of familial hyperaldosteronism that remain unexplained.

\section{Introduction}

$\checkmark$

Primary aldosteronism (PA) is a leading cause of secondary hypertension, with a prevalence of approximately $6-10 \%$ in hypertension centers [1-3]. PA involves excessive production of aldosterone despite suppressed renin and normal or low serum potassium levels. The most common causes are aldosterone-producing adenomas (APAs) and bilateral adrenal hyperplasia [2]. Familial aggregation of PA [familial hyperaldosteronism, (FH)] was initially reported in a peculiar subform, glucocorticoid-remediable aldosteronism (GRA) [4], but later also in nonglucocorticoidsuppressible hyperaldosteronism [5].

The first form of primary aldosteronism that was understood on a molecular level was GRA [6], which is due to a fusion of the promoter region of the 11 $\beta$-hydroxylase gene CYP11B1 with the coding region of the aldosterone synthase gene CYP11B2. Over the past few years, however, exome sequencing studies of APAs have identified several new genetic causes of primary aldo- 
steronism. In the case of 2 genes (KCNJ5 and CACNA1D), the discovery of tumor-specific (somatic) mutations in APAs have led to the identification of the same or related germline mutations in patients with early-onset PA and hypertension [7-10]. Germline mutations in a third gene $(C A C N A 1 H)$ were recently discovered through an exome sequencing study of patients with childhood PA [11]. This review will summarize our current knowledge on familial PA, with a focus on the recently described mutations in the calcium channel genes CACNA1D and CACNA1H.

\section{Glucocorticoid-Remediable Aldosteronism (GRA, FH-I)} $\nabla$

Glucocorticoid-remediable aldosteronism was first described by Sutherland et al. in a family of a father and his son who presented with hypertension, potassium depletion, increased aldosterone secretion, and undetectable plasma renin activity [4]. Daily administration of $2 \mathrm{mg}$ dexamethasone reversibly corrected hypertension and hypokalemia. GRA is inherited as an autosomal dominant trait; patients typically present with hypertension in the first 2 decades of life and carry an increased risk of early cerebral hemorrhage. Linkage of GRA to a chimeric gene on chromosome 8 was demonstrated in 1992 [6]. The chimeric gene results from a crossing over event between the highly homologous genes CYP11B1 (11ß-hydroxylase) and CYP11B2 (aldosterone synthase). As a consequence, aldosterone synthase is produced under the control of the $11 \beta$-hydroxylase promoter, which is normally involved in cortisol production and is therefore regulated by ACTH ( $\bullet$ Fig. 1b). This finding explained the clinical features of GRA - aldosterone is produced under the control of ACTH throughout the glucocorticoid-producing zona fasciculata, despite suppressed renin levels. Exogenous administration of dexamethasone suppresses ACTH, and thereby aldosterone production. Hybrid steroids (18-oxocortisol and 18-hydroxycortisol) arise from the joint activities of enzymes involved in cortisol and aldosterone synthesis in the zona fasciculata.

GRA should be suspected in young patients with PA, with or without hypokalemia, especially with a family history of earlyonset hypertension and/or cerebral hemorrhage. The diagnosis is based on genetic testing, and screening of first-degree relatives is recommended. Patients are typically treated with lowdose glucocorticoids and/or mineralocorticoid receptor blockers, such as spironolactone or eplerenone.

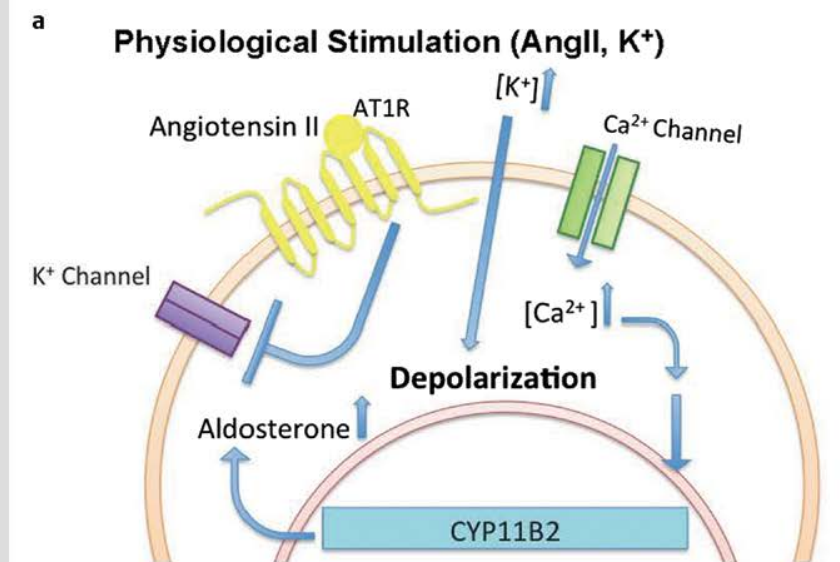

c FH-III

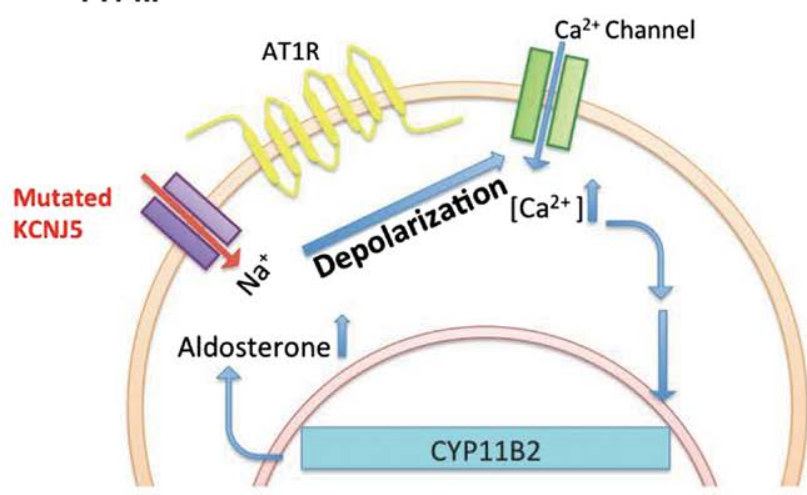

Fig. 1 Normal and pathological pathways of aldosterone biosynthesis: a Physiological Stimulation. Angiotensin II binds to the Angiotensin II type I receptor (AT1R), inhibiting potassium channels and causing depolarization. Elevated extracellular potassium concentration directly causes depolarization. The resulting activation of voltage-gated calcium channels leads to increased calcium influx, increased transcription of the CYP11B2 (aldosterone synthase) gene and aldosterone production. $\mathbf{b} \mathrm{FH}-\mathrm{I}$. Adrenocorticotropic hormone (ACTH) binds to the melanocortin 2 receptor (MC2R) and upregulates transcription of the chimeric gene resulting from the crossover between CYP11B1 b
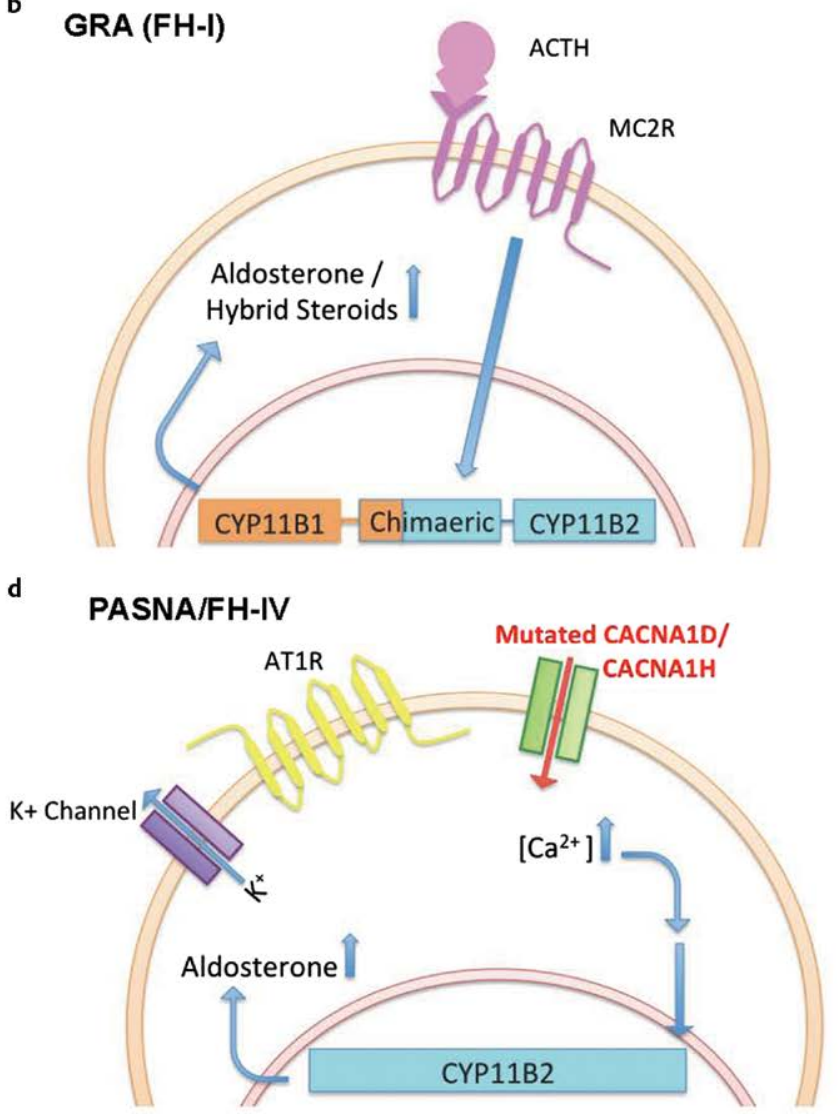

(11ß-hydroxylase) and CYP11B2 (aldosterone synthase) genes, causing excessive aldosterone production. c FH-III. Cell membrane depolarization is caused by mutations of the $K C N J 5$ gene that encodes for inward rectifier potassium channels, initiating the activation of voltage-gated calcium channels and calcium influx. This, in turn, triggers increased aldosterone biosynthesis. $\mathbf{d}$ PASNA/FH-IV. Genetic mutations in the CACNA1D or CACNA1H genes encoding voltage-dependent calcium channels cause an increase in calcium influx. Increased intracellular calcium concentration leads to increased aldosterone biosynthesis. (Color figure available online only). 


\section{Familial Hyperaldosteronism with KCNJ5 Mutations (FH-III) \\ $\sqrt{10}$}

Initially, FH-III referred to patients with massive adrenal hyperplasia refractory to dexamethasone administration [12]. However, the term is now more commonly used to describe all subjects with PA due to germline KCNJ5 mutations, independent of the phenotype.

Early observations suggested the existence of familial forms of hyperaldosteronism that do not respond to glucocorticoids. These included a family with bilateral excess secretion of aldosterone $[5,13]$. The index case was reported by Bartter and Biglieri in 1958, before spironolactone was introduced clinically. The male patient was treated by removal of the right adrenal and four-fifth of the left adrenal gland. Both glands were histologically normal [13]. His affected daughter and 2 grandchildren were treated with spironolactone, which normalized blood pressure. Another interesting family of a father and 2 daughters described by Geller et al. developed severe hyperaldosteronism, hypertension and hypokalemia at ages 4-7 years [12]. The second family presented with severe bilateral adrenal hyperplasia and did not respond to medical treatment. All members of this family required bilateral adrenalectomy, with paired adrenal weights up to $82 \mathrm{~g}$ (normal: less than $12 \mathrm{~g}$ ). Since such observations are limited to small nuclear families, the underlying genetic defect remained unknown.

The advent of next-generation sequencing, however, enabled the identification of causal genes in APAs, which proved to be valuable candidate genes in families with nonglucocorticoidsuppressible aldosteronism.

In the initial study, Choi et al. identified recurrent heterozygous somatic gain-of-function mutations of the KCNJ5 gene as a cause of about $40 \%$ of APAs [7]. KCNJ5 encodes an inward rectifier potassium channel, and the mutations affected amino acids in or close to the channel's selectivity filter. This selectivity filter allows only potassium, and not the smaller sodium ions, to pass through the channel. Two mutations, $\mathrm{KCNJ} 5^{\mathrm{G} 151 \mathrm{R}}$ and $\mathrm{KCNJ} 5^{\mathrm{L} 168 \mathrm{R}}$, account for almost all cases, and additional somatic mutations are rare. By electrophysiology, both mutations were shown to cause abnormal sodium permeability of the channel and subsequent cellular depolarization ( $\bullet$ Fig. 1c). This is an interesting mechanism because in the zona glomerulosa, binding of angiotensin II to its receptor causes inhibition of potassium channels and cellular depolarization, whereas hyperkalemia directly causes depolarization. The resulting activation of voltage-gated calcium channels leads to calcium influx, which is the signal for aldosterone production and, if present chronically, cellular proliferation [14] ( $\bullet$ Fig. 1a). Abnormal and constitutive activation of these pathways accounts for the development of aldosteroneproducing tumors. The authors reasoned that similar mutations, when present in the germline, might cause hereditary PA with massive adrenal hyperplasia, as present in the family described by Geller et al. [12]. Indeed, primary aldosteronism in this family co-segregated with the presence of a $\mathrm{KCNJ}^{\mathrm{T} 158 \mathrm{~A}}$ mutation, which caused sodium influx and depolarization [7]. The identical variant was subsequently also found as a somatic mutation in tumors $[8,15]$.

Screening of additional families identified germline $\mathrm{KCNJ} 5^{\mathrm{G} 151 \mathrm{R}}$ mutations, which had previously been described in tumors [10]. None of the 3 affected individuals from the first kindred responded to medical treatment; all required bilateral adrenalectomy, similar to the family with $\mathrm{KCNJ} 5^{\mathrm{T} 158 \mathrm{~A}}$ mutation. Pathol- ogy demonstrated adrenal hyperplasia, with the exception of the youngest individual, who had adrenalectomy at the age of 18 months, presumably before hyperplasia could develop. A single affected individual with difficult-to-control hypertension and de novo mutation in the second family was lost to follow-up. Similarly, a mother and her daughter, both with KCNJ5 $5^{11575}$ mutations, had massive adrenal hyperplasia and severe hypertension refractory to treatment; both underwent adrenalectomy [16]. An additional patient with de novo $\mathrm{KCNJ} 5^{\mathrm{E} 145 \mathrm{Q}}$ mutation previously described in an adenoma [17] had a severe phenotype and underwent adrenalectomy [18].

Most interestingly, affected members of the family with primary aldosteronism and normal adrenal histology mentioned above [5] carried a $\mathrm{KCNJ} 5^{\mathrm{G} 151 \mathrm{E}}$ mutation [10], which has never been found in tumors. The identical mutation was observed in 2 additional families, again with a much milder clinical phenotype. Patients typically responded to medical treatment with mineralocorticoid receptor antagonists and did not require bilateral adrenalectomy $[8,10,19]$. As a result, histology for assessment of potential microscopic hyperplasia is not available for the more recent cases. When heterologously expressed, the $\mathrm{KCNJ} 5^{\mathrm{G} 151 \mathrm{E}}$ mutation caused severe cell lethality, which could be rescued upon the removal of sodium from the extracellular medium, suggesting that this was a sodium-dependent effect. Indeed, by electrophysiology, it was shown that the mutation caused larger sodium currents than the previously described $\mathrm{KCNJ} 5^{\mathrm{G} 151 \mathrm{R}}$ mutation at the same residue, suggesting that sodium-dependent lethality prevents the development of macroscopic hyperplasia in these patients in vivo.

Another variant ( $\mathrm{KCNJ}^{\mathrm{Y} 152 \mathrm{C}}$, also not present in tumors) was found in a subject with a milder phenotype [20]. This individual was diagnosed with primary aldosteronism at the age of 48 years (much later than any of the other cases), but already had significant target organ damage, suggesting a longstanding history of hypertension. Unfortunately, despite a significant family history of hypertension, other family members were not available for genetic studies. Functional studies demonstrated a less pronounced effect on $\mathrm{Na}^{+}$conductance than that observed with other mutations.

From these studies, it appears that mutations found in tumors typically cause therapy resistant hyperaldosteronism and massive adrenal hyperplasia when present in the germline. The only exception so far is a Japanese patient with $\mathrm{KCNJ} 5^{\mathrm{G} 151 \mathrm{R}}$ mutation who at the age of 11 years had not developed adrenal hyperplasia and had responded to treatment with spironolactone [21]. It will be interesting to follow this case in the future.

In contrast, specific mutations that have not been found in tumors appear to cause milder forms of hyperaldosteronism, possibly as a result of sodium-dependent lethality or reduced calcium influx ( $\odot$ Table $\mathbf{1}$ ).

\section{Primary Aldosteronism with Seizures and Neurologic Abnormalities (PASNA)}

The gene with the second highest mutation burden in APAs is CACNA1D, which similar to KCNJ5 was discovered through exome sequencing studies $[9,22]$. CACNA1D encodes a voltage-gated L-type calcium channel $\left(\mathrm{Ca}_{\mathrm{V}} 1.3\right)$. CACNA1D channels are activated at large depolarizing potentials and are highly expressed in adrenal glomerulosa. Mutations identified in APAs shift the voltage dependence of activation to more hyperpolarized poten- 
Table 1 Phenotypes of families with familial hyperaldosteronism and mutations in KCNJ5, CACNA1D, or CACNA1H.

\begin{tabular}{|c|c|c|c|c|c|c|c|c|c|}
\hline Kindred & $\begin{array}{l}\text { Country } \\
\text { of origin }\end{array}$ & $\begin{array}{l}\text { \# Affected } \\
\text { subjects }\end{array}$ & $\begin{array}{l}\text { Age at diag- } \\
\text { nosis (years) }\end{array}$ & $\begin{array}{l}\text { Macroscopic } \\
\text { adrenal } \\
\text { hyperplasia }\end{array}$ & $\begin{array}{l}\text { Response } \\
\text { to medical } \\
\text { treatment }\end{array}$ & Adrenalectomy & $\begin{array}{l}\text { KCNJ5 } \\
\text { Mutation }\end{array}$ & $\begin{array}{l}\text { CACNA1D } \\
\text { Mutation }\end{array}$ & $\begin{array}{l}\text { CACNA1H } \\
\text { Mutation }\end{array}$ \\
\hline Geller et al. 2008 [12] & US & 3 & $4,5,7$ & $\mathrm{Y}, \mathrm{Y}, \mathrm{Y}$ & $\mathrm{N}, \mathrm{N}, \mathrm{N}$ & $\mathrm{Y}, \mathrm{Y}, \mathrm{Y}$ & T158A & & \\
\hline Scholl et al. 2012 [10] & US & 3 & 1,11 & $\mathrm{Y}, \mathrm{Y}, \mathrm{N}^{\mathrm{a}}$ & $\mathrm{N}, \mathrm{N}, \mathrm{N}$ & $\mathrm{Y}, \mathrm{Y}, \mathrm{Y}$ & G151R & & \\
\hline Scholl et al. 2012 [10] & UK & 1 & 4 & $\mathrm{~N} / \mathrm{A}$ & $\mathrm{N} / \mathrm{A}$ & $\mathrm{N} / \mathrm{A}$ & G151R & & \\
\hline Charmandari et al. 2012 [16] & GR & 2 & 2,7 & $\mathrm{Y}, \mathrm{Y}$ & $\mathrm{N}, \mathrm{N}$ & $\mathrm{Y}, \mathrm{Y}$ & I157S & & \\
\hline Monticone et al. 2015 [18] & US & 1 & 2 & $\mathrm{Y}$ & $\mathrm{N}$ & Y & E145Q & & \\
\hline Adachi et al. 2014 [21] & 小 & 1 & 4 & $\mathrm{~N}$ & Y & $\mathrm{N}$ (age 11) & G151R & & \\
\hline $\begin{array}{l}\text { Mulatero et al. } 2012 \text { [8] and } \\
\text { Mussa et al. } 2012 \text { [19] }\end{array}$ & 1 & 2 & 2,18 & $\mathrm{~N}, \mathrm{~N}$ & $\mathrm{Y}, \mathrm{Y}$ & $\mathrm{N}, \mathrm{N}$ & G151E & & \\
\hline Scholl et al. 2012 [10] & US & 4 & $0.2,1,2,11$ & $\mathrm{~N}, \mathrm{~N}, \mathrm{~N}, \mathrm{~N}$ & $\mathrm{Y}, \mathrm{Y}, \mathrm{Y}, \mathrm{N}^{\mathrm{b}}$ & $\mathrm{N}, \mathrm{N}, \mathrm{N}, \mathrm{Y}^{\mathrm{b}}$ & G151E & & \\
\hline Scholl et al. 2012 [10] & $C$ & 2 & $4,<6$ & $\mathrm{~N}, \mathrm{~N} / \mathrm{A}$ & $\mathrm{Y}, \mathrm{N} / \mathrm{A}$ & $N, Y^{b}$ & G151E & & \\
\hline Monticone et al. 2013 [20] & US & 1 & 48 & $\mathrm{Y}$ & $\mathrm{N}$ & $\mathrm{Y}^{\mathrm{c}}$ & Y152C & & \\
\hline Scholl et al. 2013 [9] & US & 1 & 0 & $\mathrm{~N} / \mathrm{A}$ & Y & $\mathrm{N}$ & & G403D & \\
\hline Scholl et al. 2013 [9] & US & 1 & 5 & $\mathrm{~N}$ & Y & $\mathrm{N}$ & & $1770 \mathrm{M}$ & \\
\hline Scholl et al. 2015 [11] & US & $\begin{array}{l}8 \text { (plus } 2 \text { car- } \\
\text { riers without } \\
\text { hypertension } \\
\text { in adult- } \\
\text { hood) }\end{array}$ & $\begin{array}{l}3,7,8,9,0.2 \\
5,17,24\end{array}$ & $\begin{array}{l}\mathrm{N}, \mathrm{N}, \mathrm{N}, \mathrm{N}, \mathrm{N} / \\
\mathrm{A}, \mathrm{N}, \mathrm{N}, \mathrm{N} / \mathrm{A}\end{array}$ & $Y, Y, Y, Y, Y, Y, Y, Y$ & $\mathrm{~N}, \mathrm{~N}, \mathrm{~N}, \mathrm{~N}, \mathrm{~N}, \mathrm{~N}, \mathrm{Y}^{\mathrm{c}}, \mathrm{N}$ & & & M1549V \\
\hline
\end{tabular}

C: Canada; GR: Greece; J: Japan; I: Italy; UK: United Kingdom; US: United States; N/A: Not available

${ }^{\text {a At age }} 18$ months; ${ }^{\mathrm{b}}$ Before aldosterone antagonists became available; 'Unilateral adrenalectomy without cure

tials; some mutations also affect inactivation. These observations suggest that CACNA1D mutations directly cause increased calcium influx, aldosterone production and proliferation. By analogy with KCNJ5, the authors of one study reasoned that CACNA1D germline mutations might cause a syndrome of primary aldosteronism. They chose gene regions with recurrent mutations in adenomas and sequenced those in 100 cases of early-onset PA. Remarkably, they identified 2 individuals with germline mutations (CACNA1D ${ }^{\mathrm{G} 403 \mathrm{D}}$ and CACNA1D ${ }^{\mathrm{I770M}}$ ) [9] (○ Table 1). The mutation I770M had been found as a somatic mutation before, and G403D occurred at the identical position previously found to carry a somatic G403R mutation. Both affected children were born to healthy parents, and both mutations were shown to occur de novo.

The first subject was a 3-year old female who as a newborn had severe hypertension (blood pressure 199/78 mm Hg), biventricular hypertrophy, and a ventricular septum defect. Laboratory evaluation suggested PA, with elevated aldosterone, suppressed renin, and hypokalemia. In addition, however, the patient was diagnosed with seizures, which started at the age of 7 months, cerebral palsy, cortical blindness, and neurologic abnormalities. Interestingly, blood pressure improved upon treatment with amlodipine, and recent follow-up (unpublished) showed cure of hypertension and primary aldosteronism. The second subject was a 10-year old female who at the age of 5 years had severe hypertension (blood pressure $132 / 90 \mathrm{~mm} \mathrm{Hg}$ ), mild ventricular hypertrophy, and primary aldosteronism with hyperkalemia. There was no evidence of hyperplasia on adrenal CT scan. The subject was also diagnosed with cerebral palsy, spastic quadriplegia, mild athetosis, severe generalized intellectual disability, and complex partial and generalized seizures. Expression of CACNA1D in the brain raises the possibility that the neurological phenotype in these patients arises from abnormal neuronal calcium signaling. However, the fact that only 2 subjects have been reported so far and that both also had a complicated perinatal history (sinus bradycardia, intubation with respiratory distress, transient hypoglycemia in one case; resus- citation after uterine rupture in the second case) complicates any genotype-phenotype correlations. Mouse models may prove instructive for these cases.

Lastly, it should be noted that somatic mutations in members of the P-Type ATPase family (ATP1A1, encoding part of the $\mathrm{Na}^{+}-\mathrm{K}^{+}$-ATPase, and ATP2B3, encoding the plasma membrane $\mathrm{Ca}^{2+}$ ATPase) have been reported in APAs [22,23]. No corresponding germline variants have been reported; such variants may not be compatible with survival.

\section{Primary Aldosteronism due to CACNA1H Mutations (FH-IV)}

Most recently, a recurrent germline mutation in another voltage-gated calcium channel, $\mathrm{Ca}_{\mathrm{V}} 3.2$, encoded by the $C A C N A 1 H$ gene, was reported as a cause of early-onset primary hyperaldosteronism and hypertension [11]. CACNA1H is highly expressed in the adrenal glomerulosa and is activated at small depolarizing potentials. Is has previously been implicated in glomerulosa membrane potential oscillations and aldosterone production [24].

In the genetic study, the exomes of 40 individuals were sequenced. All had early-onset primary aldosteronism (diagnosed at age 10 years or below), and none had mutations in known genes. Five individuals had an identical, novel, heterozygous CACNA1 $\mathrm{H}^{\mathrm{M} 1549 \mathrm{~V}}$ mutation ( $\odot$ Table 1 ). Family analysis showed that 2 mutations occurred de novo (one in the affected subject, another in the affected carrier mother of the index case). In the remaining 3 cases ( 2 of European, one of Hispanic ancestry), the mutation was inherited from a parent, and no samples were available from grandparents for further analysis of transmission, raising the question whether the variant had been inherited from a common ancestor. Genotyping demonstrated that the carriers were not closely related and further suggested that the variant was either inherited from a very remote common ancestor or arose independently in each case (more likely given its absence from databases). 
Finding a recurrent de novo protein-altering mutation and finding the identical, never before seen mutation in 3 independent individuals from a cohort of 40 subjects is highly unlikely to occur by chance, implicating the CACNA1H variant in primary aldosteronism.

All index cases had primary aldosteronism and severe hypertension $\left(>99^{\text {th }}\right.$ percentile); primary aldosteronism in a large kindred was shown to segregate with the occurrence of the CACNA1H ${ }^{\mathrm{M} 1549 \mathrm{~V}}$ mutation.

Interestingly, however, while kindred analysis suggested autosomal dominant inheritance, 2 of the carrier parents did not show hyperaldosteronism or hypertension in adulthood and had not been studied in childhood; one had borderline-low renin levels. Potential explanations for incomplete penetrance of the phenotype include remission with age (as previously observed in one of the CACNA1D germline cases), somatic mosaicism and/or effects of additional genetic or environmental variables. Future animal studies may be instrumental in identifying the underlying mechanisms. The CACNA1 $\mathrm{H}^{\mathrm{M} 1549 \mathrm{~V}}$ mutation was also expressed in the adrenal glomerulosa of a subject who had undergone unilateral adrenalectomy in an attempt to treat hypertension. Interestingly, her adrenal gland showed micronodular adrenal hyperplasia with invasion of the capsule, without macroscopic hyperplasia. On electrophysiology, CACNA1 $\mathrm{H}^{\mathrm{M} 1549 \mathrm{~V}}$ caused reduced inactivation of the calcium channel, as well as a slight shift to more hyperpolarized potentials, effects that collectively cause increased calcium influx similar to the mechanism seen in CACNA1D mutations (० Fig. 1d).

In contrast with patients with the PASNA syndrome, subjects with the CACNA1H mutation do not share any extraadrenal symptoms. No CACNA1H mutations have been identified in APAs, suggesting that this variant may not be sufficient to cause the proliferation seen in KCNJ5 mutations.

The incomplete penetrance, in combination with the high frequency of de novo mutations, explains why this gene had not been identified from linkage analysis alone. Solving such cases will likely prove to be a major strength of exome and/or genome sequencing.

\section{Potential Role of ARMC5 Mutations in FH}

$\nabla$

ARMC5 loss-of-function variants have been implicated in Cushing's syndrome with bilateral macronodular adrenal hyperplasia [25]. In all cases, nodules carried ARMC5 mutations on both alleles: a germline mutation and a "second hit" specific to the nodule. A recent report similarly implicated ARMC5 variants in primary aldosteronism. However, the evidence for a causal role is much weaker than in Cushing's syndrome. Of the patients in the cohort, $11 \%$ carried variants predicted to be damaging by in silico analysis, but in contrast with Cushing's syndrome no concurrent somatic mutations were observed. Moreover, all variants occurred in African Americans, who carry a high overall burden of rare variants [26]. Further studies will be needed to assess any role of $A R M C 5$ variants in $\mathrm{FH}$.

\section{Familial Hyperaldosteronism Without Mutations in Known Genes (FH-II)}

Additional families with primary aldosteronism have been described without known mutations; these are now commonly referred to as FH-II and include both cases with adrenocortical adenomas and bilateral hyperplasia. When relaxed criteria are used (diagnosis of primary aldosteronism in 2 or more members of the same family) [27], up to $6 \%$ of cases of primary aldosteronism in referral centers may be classified as familial. However, such numbers should be treated with caution. Considering the high prevalence of hypertension in the general population (about $30 \%$ ) and using a conservative estimate of about $5 \%$ for the prevalence of primary aldosteronism among hypertensive adults, the likelihood for each adult family member tested to be diagnosed with primary aldosteronism by chance alone would be about $1.5 \%$. If, in addition to the index case, more family members are screened, for example, 4 additional individuals within a single family, the likelihood of finding at least one individual with primary aldosteronism by chance alone would be $\sim 5.9 \%$. Unless rare and distinctive traits, such as the presence of hybrid steroids in GRA, early-onset disease or massive hyperplasia are present, small families may not prove to be instructive in identifying additional genes in $\mathrm{FH}$.

Such effects, in combination with incomplete penetrance, may explain why causative mutations remain to be determined in many cases of FH-II. Prior linkage to chromosome 7p22 has so far not led to the identification of causative mutations [28-31]. Nonetheless, studies on some families have been published in whom the presence of a monogenic disorder appears very likely, including a very large kindred first reported by Torpy et al. in 1998 [32]. Next-generation sequencing is expected to be instructive in such cases.

\section{Approach to Patients with Suspected Familial Forms of Primary Aldosteronism}

Given the above considerations, and in line with the recommendations of the Endocrine Society [2], we suggest performing genetic testing in patients who present with primary aldosteronism at less than 20 years of age and in patients with a positive family history of early-onset hypertension, primary aldosteronism, or cerebral hemorrhage. Such testing can be performed in a clinical or a research setting.

\section{Acknowledgements}

$\nabla$

U.I.S. was supported by the Ministry of Innovation, Science and Research of the State of North Rhine-Westphalia, Germany.

\section{Conflict of Interest \\ $\nabla$}

The authors declare no conflict of interest.

\section{References}

1 Rossi GP, Bernini G, Caliumi C, Desideri G, Fabris B, Ferri C, Ganzaroli C, Giacchetti G, Letizia C, Maccario M, Mallamaci F, Mannelli M, Mattarello MJ, Moretti A, Palumbo G, Parenti G, Porteri E, Semplicini A, Rizzoni D, Rossi E, Boscaro M, Pessina AC, Mantero F. A prospective study of the prevalence of primary aldosteronism in 1,125 hypertensive patients. J Am Coll Cardiol 2006; 48: 2293-2300

2 Funder JW, Carey RM, Fardella C, Gomez-Sanchez CE, Mantero F, Stowasser M, Young WF Jr, Montori VM. Case detection, diagnosis, and treatment of patients with primary aldosteronism: an endocrine society clinical practice guideline. J Clin Endocrinol Metab 2008; 93: 3266-3281 
3 Mosso L, Carvajal C, Gonzalez A, Barraza A, Avila F, Montero J, Huete $A$, Gederlini A, Fardella CE. Primary aldosteronism and hypertensive disease. Hypertension 2003; 42: 161-165

4 Sutherland DJ, Ruse JL, Laidlaw JC. Hypertension, increased aldosterone secretion and low plasma renin activity relieved by dexamethasone. Can Med Assoc J 1966; 95: 1109-1119

5 Greco RG, Carroll JE, Morris DJ, Grekin RJ, Melby JC. Familial hyperaldosteronism, not suppressed by dexamethasone. J Clin Endocrinol Metab 1982; 55: 1013-1016

6 Lifton RP, Dluhy RG, Powers M, Rich GM, Cook S, Ulick S, Lalouel JM. A chimaeric 11 beta-hydroxylase/aldosterone synthase gene causes glucocorticoid-remediable aldosteronism and human hypertension. Nature 1992; 355: 262-265

7 Choi M, Scholl UI, Yue P, Bjorklund P, Zhao B, Nelson-Williams C, Ji W, Cho Y, Patel A, Men CJ, Lolis E, Wisgerhof MV, Geller DS, Mane S, Hellman P, Westin G, Akerstrom G, Wang W, Carling T, Lifton RP. K+ channel mutations in adrenal aldosterone-producing adenomas and hereditary hypertension. Science 2011; 331: 768-772

8 Mulatero P, Tauber P, Zennaro MC, Monticone S, Lang K, Beuschlein F, Fischer E, Tizzani D, Pallauf A, Viola A, Amar L, Williams TA, Strom TM, Graf E, Bandulik S, Penton D, Plouin PF, Warth R, Allolio B, Jeunemaitre $X$, Veglio F, Reincke M. KCNJ5 mutations in European families with nonglucocorticoid remediable familial hyperaldosteronism. Hypertension 2012; 59: 235-240

9 Scholl UI, Goh G, Stolting G, de Oliveira RC, Choi M, Overton JD, Fonseca $A L$, Korah R, Starker LF, Kunstman JW, Prasad ML, Hartung EA, Mauras $N$, Benson MR, Brady T, Shapiro JR, Loring E, Nelson-Williams C, Libutti SK, Mane S, Hellman P, Westin G, Akerstrom G, Bjorklund P, Carling T, Fahlke $C$, Hidalgo $P$, Lifton RP. Somatic and germline CACNA1D calcium channel mutations in aldosterone-producing adenomas and primary aldosteronism. Nat Genet 2013; 45: 1050-1054

10 Scholl UI, Nelson-Williams C, Yue P, Grekin R, Wyatt RJ, Dillon MJ, Couch $R$, Hammer LK, Harley FL, Farhi A, Wang WH, Lifton RP. Hypertension with or without adrenal hyperplasia due to different inherited mutations in the potassium channel KCNJ5. Proc Natl Acad Sci USA 2012; 109: 2533-2538

11 Scholl UI, Stolting G, Nelson-Williams C, Vichot AA, Choi M, Loring E, Prasad ML, Goh G, Carling T, Juhlin CC, Quack I, Rump LC, Thiel A, Lande M, Frazier BG, Rasoulpour M, Bowlin DL, Sethna CB, Trachtman H, Fahlke $C$, Lifton RP. Recurrent gain of function mutation in calcium channel CACNA1H causes early-onset hypertension with primary aldosteronism. eLife 2015; 4

12 Geller DS, Zhang J, Wisgerhof MV, Shackleton C, Kashgarian M, Lifton RP. A novel form of human mendelian hypertension featuring nonglucocorticoid-remediable aldosteronism. J Clin Endocrinol Metab 2008; 93: 3117-3123

13 Bartter FC, Biglieri EG. Primary aldosteronism: clinical staff conference at the National Institutes of Health. Ann Intern Med 1958; 48: 647-654

14 Spat A, Hunyady L. Control of aldosterone secretion: a model for convergence in cellular signaling pathways. Physiol Rev 2004; 84: 489-539

15 Wang B, Li X, Zhang X, Ma X, Chen L, Zhang Y, Lyu X, Tang Y, Huang $Q$ Gao $Y$, Fan $Y$, Ouyang J. Prevalence and characterization of somatic mutations in chinese aldosterone-producing adenoma patients. Medicine (Baltimore) 2015; 94: e708

16 Charmandari E, Sertedaki A, Kino T, Merakou C, Hoffman DA, Hatch MM, Hurt DE, Lin L, Xekouki P, Stratakis CA, Chrousos GP. A Novel Point Mutation in the KCNJ5 Gene Causing Primary Hyperaldosteronism and Early-Onset Autosomal Dominant Hypertension. J Clin Endocrinol Metab 2012; 97: E1532-E1539

17 Akerstrom T, Crona J, Delgado Verdugo A, Starker LF, Cupisti K, Willenberg HS, Knoefel WT, Saeger W, Feller A, Ip J, Soon P, Anlauf M, Alesina PF, Schmid KW, Decaussin M, Levillain P, Wangberg B, Peix JL, Robinson $B$, Zedenius J, Backdahl M, Caramuta S, Iwen KA, Botling J, Stalberg P, Kraimps JL, Dralle H, Hellman P, Sidhu S, Westin G, Lehnert H, Walz MK, Akerstrom G, Carling T, Choi M, Lifton RP, Bjorklund P. Comprehensive Re-Sequencing of Adrenal Aldosterone Producing Lesions Reveal Three Somatic Mutations near the KCNJ5 Potassium Channel Selectivity Filter. PLoS One 2012; 7: e41926
18 Monticone S, Bandulik S, Stindl J, Zilbermint M, Dedov I, Mulatero P, Allgaeuer M, Lee CC, Stratakis CA, Williams TA, Tiulpakov A. A case of severe hyperaldosteronism caused by a de novo mutation affecting a critical salt bridge Kir3.4 residue. J Clin Endocrinol Metab 2015; 100: E114-E118

19 Mussa A, Camilla R, Monticone S, Porta F, Tessaris D, Verna F, Mulatero P, Einaudi $S$. Polyuric-polydipsic syndrome in a pediatric case of nonglucocorticoid remediable familial hyperaldosteronism. Endocr J 2012; 59: 497-502

20 Monticone S, Hattangady NG, Penton D, Isales CM, Edwards MA, Williams TA, Sterner C, Warth R, Mulatero P, Rainey WE. A Novel Y152C KCNJ5 Mutation Responsible for Familial Hyperaldosteronism Type III. J Clin Endocrinol Metab 2013; 98: E1861-E1865

21 Adachi M, Muroya K, Asakura Y, Sugiyama K, Homma K, Hasegawa T. Discordant Genotype-Phenotype Correlation in Familial Hyperaldosteronism Type III with KCNJ5 Gene Mutation: A Patient Report and Review of the Literature. Horm Res Paediatr 2014; 82: 138-142

22 Azizan EA, Poulsen H, Tuluc P, Zhou J, Clausen MV, Lieb A, Maniero C, Garg S, Bochukova EG, Zhao W, Shaikh LH, Brighton CA, Teo AE, Davenport AP, Dekkers T, Tops B, Kusters B, Ceral J, Yeo GS, Neogi SG, McFarlane I, Rosenfeld N, Marass F, Hadfield J, Margas W, Chaggar K, Solar M, Deinum J, Dolphin AC, Farooqi IS, Striessnig J, Nissen P, Brown MJ. Somatic mutations in ATP1A1 and CACNA1D underlie a common subtype of adrenal hypertension. Nat Genet 2013; 45: 1055-1060

23 Beuschlein F, Boulkroun S, Osswald A, Wieland T, Nielsen HN, Lichtenauer UD, Penton D, Schack VR, Amar L, Fischer E, Walther A, Tauber P, Schwarzmayr T, Diener S, Graf E, Allolio B, Samson-Couterie $B$, Benecke A, Quinkler M, Fallo F, Plouin PF, Mantero F, Meitinger T, Mulatero P, Jeunemaitre X, Warth R, Vilsen B, Zennaro MC, Strom TM, Reincke M. Somatic mutations in ATP1A1 and ATP2B3 lead to aldosterone-producing adenomas and secondary hypertension. Nat Genet 2013; 45: 440-444

$24 \mathrm{Hu}$ C, Rusin CG, Tan Z, Guagliardo NA, Barrett PQ. Zona glomerulosa cells of the mouse adrenal cortex are intrinsic electrical oscillators. J Clin Invest 2012; 122: 2046-2053

25 Assie G, Libe R, Espiard S, Rizk-Rabin M, Guimier A, Luscap W, Barreau $O$, Lefevre L, Sibony M, Guignat L, Rodriguez S, Perlemoine K, Rene-Corail F, Letourneur F, Trabulsi B, Poussier A, Chabbert-Buffet N, Borson-Chazot $F$, Groussin L, Bertagna X, Stratakis CA, Ragazzon B, Bertherat J. ARMC5 mutations in macronodular adrenal hyperplasia with Cushing's syndrome. N Engl J Med 2013; 369: 2105-2114

26 Genomes Project C.Abecasis GR, Auton A, Brooks LD, DePristo MA, Durbin RM, Handsaker RE, Kang HM, Marth GT, McVean GA. An integrated map of genetic variation from 1,092 human genomes. Nature 2012; 491: 56-65

27 Mulatero P, Tizzani D, Viola A, Bertello C, Monticone S, Mengozzi G, Schiavone D, Williams TA, Einaudi S, La Grotta A, Rabbia F, Veglio F. Prevalence and characteristics of familial hyperaldosteronism: the PATOGEN study (Primary Aldosteronism in TOrino-GENetic forms). Hypertension 2011; 58: 797-803

28 Carss KJ, Stowasser M, Gordon RD, O'Shaughnessy KM. Further study of chromosome 7p22 to identify the molecular basis of familial hyperaldosteronism type II. J Hum Hypertens 2011; 25: 560-564

29 So A, Duffy DL, Gordon RD, Jeske YW, Lin-Su K, New MI, Stowasser M. Familial hyperaldosteronism type II is linked to the chromosome 7p22 region but also shows predicted heterogeneity. J Hypertens 2005; 23: $1477-1484$

30 Sukor N, Mulatero P, Gordon RD, So A, Duffy D, Bertello C, Kelemen L, Jeske $Y$, Veglio F, Stowasser M. Further evidence for linkage of familial hyperaldosteronism type II at chromosome 7p22 in Italian as well as Australian and South American families. J Hypertens 2008; 26 : 1577-1582

31 Lafferty AR, Torpy DJ, Stowasser M, Taymans SE, Lin JP, Huggard P, Gordon $R D$, Stratakis $C A$. A novel genetic locus for low renin hypertension: familial hyperaldosteronism type II maps to chromosome 7 (7p22). J Med Genet 2000; 37: 831-835

32 Torpy DJ, Gordon RD, Lin JP, Huggard PR, Taymans SE, Stowasser $M$, Chrousos GP, Stratakis CA. Familial hyperaldosteronism type II: description of a large kindred and exclusion of the aldosterone synthase (CYP11B2) gene. J Clin Endocrinol Metab 1998; 83: 3214-3218 